University of Nebraska - Lincoln

DigitalCommons@University of Nebraska - Lincoln

Comparative embryotoxicity of a pentabrominated diphenyl ether mixture to common terns (Sterna hirundo) and American kestrels (Falco sparverius)

\author{
Barnett A. Rattner \\ Rebecca S. Lazarus \\ United States Geological Survey \\ Gary H. Heinz \\ United States Geological Survey \\ Natalie K. Karouna-Renier \\ United States Geological Survey \\ Sandra L. Schultz \\ United States Geological Survey
}

United States Geological Survey, brattner@usgs.gov

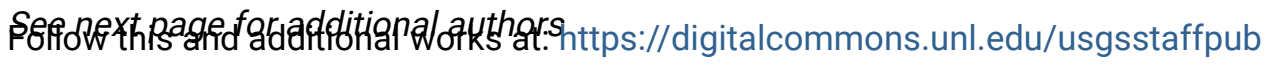 \\ Part of the Geology Commons, Oceanography and Atmospheric Sciences and Meteorology Commons, Other Earth Sciences Commons, and the Other Environmental Sciences Commons
}

Rattner, Barnett A.; Lazarus, Rebecca S.; Heinz, Gary H.; Karouna-Renier, Natalie K.; Schultz, Sandra L.; and Hale, Robert C., "Comparative embryotoxicity of a pentabrominated diphenyl ether mixture to common terns (Sterna hirundo) and American kestrels (Falco sparverius)" (2013). USGS Staff -- Published Research. 954.

https://digitalcommons.unl.edu/usgsstaffpub/954

This Article is brought to you for free and open access by the US Geological Survey at DigitalCommons@University of Nebraska - Lincoln. It has been accepted for inclusion in USGS Staff -- Published Research by an authorized administrator of DigitalCommons@University of Nebraska - Lincoln. 


\section{Authors}

Barnett A. Rattner, Rebecca S. Lazarus, Gary H. Heinz, Natalie K. Karouna-Renier, Sandra L. Schultz, and Robert C. Hale 


\title{
Comparative embryotoxicity of a pentabrominated diphenyl ether mixture to common terns (Sterna hirundo) and American kestrels (Falco sparverius)
}

\author{
Barnett A. Rattner ${ }^{\mathrm{a}, *}$, Rebecca S. Lazarus ${ }^{\mathrm{a}}$, Gary H. Heinz ${ }^{\mathrm{a}}$, Natalie K. Karouna-Renier ${ }^{\text {a }}$, Sandra L. Schultz ${ }^{\mathrm{a}}$, \\ Robert C. Hale ${ }^{\mathrm{b}}$ \\ ${ }^{a}$ Patuxent Wildife Research Center, US Geological Survey, c/o BARC-East, Building 308, 10300 Baltimore Avenue, Beltsville, MD 20705, USA \\ ${ }^{\mathrm{b}}$ Department of Environment and Aquatic Animal Health, Virginia Institute of Marine Science, Gloucester Point, VA 23062, USA
}

\section{H I G H L I G H T S}

- Forster's tern eggs from San Francisco Bay contain high residues of PBDEs.

- Relative sensitivity of terns to PBDEs is of importance to natural resource managers.

- PBDE-treated common tern and American kestrel eggs hatched later than controls.

- Oxidative stress and DNA damage was more pronounced in hatchling kestrels than terns.

- Findings suggest that tern embryos are less sensitive to PBDEs than kestrel embryos.

\section{A R T I C L E I N F O}

\section{Article history:}

Received 8 December 2012

Received in revised form 27 April 2013

Accepted 5 May 2013

Available online 14 June 2013

\section{Keywords:}

Birds

Embryotoxicity

PBDE

Egg injection

Common tern

American kestrel

\begin{abstract}
A B S T R A C T
Concentrations of polybrominated diphenyl ethers (PBDEs) in Forster's tern (Sterna forsteri) eggs from San Francisco Bay have been reported to range up to $63 \mu \mathrm{gg}^{-1}$ lipid weight. This value exceeds the lowest-observed-adverse-effect level $\left(1.8 \mu \mathrm{g} \mathrm{g}^{-1}\right.$ egg wet weight; $\sim 32 \mu \mathrm{g} \mathrm{g}^{-1}$ lipid weight) reported in an embryotoxicity study with American kestrels (Falco sparverius). As a surrogate for Forster's terns, common tern (Sterna hirundo) eggs were treated by air cell injection with corn oil vehicle (control) or a commercial penta-BDE formulation (DE-71) at nominal concentrations of $0.2,2$, and $20 \mu \mathrm{g} \mathrm{g}^{-1}$ egg. As a positive control, kestrel eggs received vehicle or $20 \mu \mathrm{g} \mathrm{DE}-71 \mathrm{~g}^{-1}$ egg. In terns, there were no effects of DE-71 on embryonic survival, and pipping or hatching success; however, treated eggs hatched later $(0.44 \mathrm{~d})$ than controls. Organ weights, organ-to-body weight ratios, and bone lengths did not differ, and histopathological observations were unremarkable. Several measures of hepatic oxidative stress in hatchling terns were not affected by DE-71, although there was some evidence of oxidative DNA damage (8-hydroxy-deoxyguanosine; 8-OH-dG). Although DE-71 did not impair pipping and hatching of kestrels, it did result in a delay in hatch, shorter humerus length, and reduced total thyroid weight. Concentrations of oxidized glutathione, reduced glutathione, thiobarbituric acid reactive substances, and 8-OH-dG in liver were greater in DE-71-treated kestrels compared to controls. Our findings suggest common tern embryos, and perhaps other tern species, are less sensitive to PBDEs than kestrel embryos.
\end{abstract}

Published by Elsevier Ltd.

\section{Introduction}

San Francisco Bay provides critical habitat for millions of birds, contains three Important Bird Areas, and has been designated as a Wetland of Hemispheric Importance (Chipley et al., 2003). Pesticides, industrial chemicals, metals and other anthropogenic compounds enter the Bay through runoff, sewage outfalls, atmospheric deposition, and constitute a potential threat to fish

\footnotetext{
* Corresponding author. Tel.: +1 301497 5671; fax: +1 3014975624 .

E-mail address: brattner@usgs.gov (B.A. Rattner).
}

and wildlife resources. Since the 1970s, polybrominated diphenyl ethers (PBDEs) have been used as additive flame retardants in polymers, textiles, and electronics. Due to their persistence, bioaccumulation and potential toxicity, the United States Environmental Protection Agency (US EPA) and manufacturers reached agreement to phase out the use of certain penta- and octa-BDE formulations by 2004 , and more recently agreed to phase out the use of the deca-BDE formulation by the end of 2013 (US EPA, 2012). Many BDE congeners have been demonstrated to biomagnify in aquatic and terrestrial food webs, with concentrations in eggs of high trophic level birds in North America ranging up to $6.61 \mu \mathrm{g} \mathrm{g}^{-1}$ wet 
weight (ww) (Chen et al., 2008; Henny et al., 2009; Chen and Hale, 2010; D. Chen, Southern Illinois University, personal communication). However, in San Francisco Bay, total PBDE concentrations range up to $63 \mu \mathrm{g} \mathrm{g}^{-1}$ lipid weight (lw) $\left(\sim 10 \mu \mathrm{g} \mathrm{g}^{-1} \mathrm{ww}\right)$ in eggs of Forster's terns (Sterna forsteri), a lower trophic level species (She et al., 2008). These findings are of concern to natural resource managers since the closely related endangered California least tern (Sterna antillarum browni) breeds in this region. There is some evidence that PBDEs may adversely affect reproduction in wild birds. Henny et al. (2009) suggested that osprey (Pandion haliaetus) productivity decreases at PBDE concentrations exceeding $1 \mu \mathrm{g} \mathrm{g}^{-1} \mathrm{ww}$ in eggs, although this finding was not supported in a subsequent study (Henny et al., 2011). In peregrine falcons (Falco peregrinus), brood size was found to be inversely related to total PBDE residues in eggs (0.68-39 $\mathrm{ng} \mathrm{g}^{-1} \mathrm{lw}$ ) (Johansson et al., 2009).

Studies of birds have examined sublethal biochemical, immunological, developmental and reproductive effects of environmentally relevant concentrations of PBDEs (Chen and Hale, 2010). Using American kestrels (Falco sparverius), Fernie et al. (2006) injected $1.43 \mu \mathrm{g}$ of a PBDE mixture $\mathrm{g}^{-1}$ egg on d 19 of incubation, followed by daily oral gavage of nestlings with $15.6 \mathrm{ng} \mathrm{g}^{-1}$ body weight for $29 \mathrm{~d}$ post-hatch. Using this combined egg injection/gavage exposure regime, there was some evidence that PBDEs increased growth (i.e., body weight, tarsometatarsus and feather length), caused structural changes in immune organs and alterations in immune function, and evoked hepatic oxidative stress (Fernie et al., 2005a,b, 2006). Concentrations of plasma thyroxine and retinol, and hepatic retinol were found to be inversely related to carcass concentrations of BDE-47 and -99 (Fernie et al., 2005b). Changes in reproductive behavior, delays in egg laying, smaller eggs and reduced fertility were observed in kestrels receiving daily dietary doses of 0.3 or 1.66 ppm of DE-71 (Fernie et al., 2008). Perhaps more germane to the interpretation of avian egg PBDE concentrations, chicken (Gallus gallus), mallard (Anas platyrhynchos) and kestrel eggs were treated with the penta-BDE formulation DE-71 at doses ranging from 0.01 to $20 \mu \mathrm{g} \mathrm{g}^{-1} \mathrm{egg}$ (McKernan et al., 2009, 2010). Measurement of the quantity of the air cell injected DE-71 that actually entered the egg contents indicated that the lowest-observed-adverse-effect level on pipping and hatching success in kestrels was $1.8 \mu \mathrm{g} \mathrm{g}^{-1}$ egg ww $\left(\sim 32 \mu \mathrm{g} \mathrm{g}^{-1} \mathrm{lw}\right)$. This threshold has been exceeded in some egg samples from free ranging birds (Chen et al., 2008; She et al., 2008; Henny et al., 2009; Johansson et al., 2009).

Toxicological information about the effects of PBDEs on common terns, a surrogate for Forster's and California least terns nesting in San Francisco Bay, would be of assistance to natural resource managers assessing the risk these flame retardants pose to birds. The present study evaluated embryonic survival, pipping and hatching success of common terns following air cell administration of DE-71, examined embryos and tern hatchlings for evidence of sublethal effects (deformities, growth, histopathologic lesions, and oxidative stress), and compared their relative sensitivity to kestrels and other similarly tested species.

\section{Materials and methods}

\subsection{Egg collection}

All procedures involving eggs were approved by the Institutional Animal Care and Use Committee of the Patuxent Wildlife Research Center (PWRC). On May 25, 2010, a visit was made to the common tern colony on Poplar Island $\left(38.7519^{\circ} \mathrm{N},-76.3792^{\circ} \mathrm{W}\right)$ in Chesapeake Bay, MD, USA. Nests containing only one egg were marked to enable identification of new eggs during a second visit. In accord with our state and federal migratory bird permits, on
May 27, a total of 60 freshly laid common tern eggs were collected from either single-egg unmarked nests or previously marked nests that contained a recently laid second egg. The eggs were transported in cartons back to PWRC, and then weighed, numbered, and left tilted on their side overnight at room temperature (approximately $21^{\circ} \mathrm{C}$ ).

American kestrel eggs were collected between April 8-14, 2010 from a captive colony at PWRC. The eggs were stored in a cooler (Kuhl Corporation, Flemington, NJ, USA) at approximately 11$13{ }^{\circ} \mathrm{C}$ and $70-76 \%$ relative humidity $(\mathrm{RH})$, and were rotated $60^{\circ}$ every hour. On April 15, the eggs were removed from the cooler to equilibrate to room temperature.

\subsection{Incubation of eggs}

Eggs were washed in a $40{ }^{\circ} \mathrm{C}$ solution of $1 \%$ antimicrobial solution (10\% povidone-iodine, Aplicare ${ }^{\circledR}$, Meriden, CT, USA), rinsed in $40{ }^{\circ} \mathrm{C}$ tap water, air dried, and then placed on their sides in a Kuhl ${ }^{\circledR}$ incubator maintained at $37.5^{\circ} \mathrm{C}$ (kestrel eggs: April 15; tern eggs: May 28). The incubator rotated eggs $180^{\circ}$ each hour. When the eggs of most species of birds are incubated by the parents they lose about $15 \%$ of their weight by pipping (Rahn and Ar, 1974). Based on our own experiences with artificial incubation of bird eggs, we adjusted this value to $16 \%$ (Klimstra et al., 2009). To achieve this desired weight loss, each egg was weighed at 2-4 d intervals, and its weight was plotted. Eggs were shifted among three incubators, each with a different RH setting (low 13-33\%; medium 58-73\%; high $70-76 \%$ ) to keep each egg on a trajectory of a $16 \%$ loss by pipping. Percent moisture loss was estimated as the [(fresh weightweight at pipping)/fresh weight] $\times 100$.

When eggs were weighed, survival was determined by candling and a viability detection instrument (Buddy ${ }^{\circledR}$; Vetronic, Torquay, UK). Tern eggs (June 16) and kestrel eggs (May 9) were transferred to a Kuhl ${ }^{\circledR}$ hatching unit set at $37.2{ }^{\circ} \mathrm{C}$ and approximately $70 \% \mathrm{RH}$. Once the first egg hatched (terns: June 18; kestrel: May 12), eggs were monitored frequently from $0700 \mathrm{~h}$ to $2345 \mathrm{~h}$. During daylight hours, hatching time was determined by direct observation, and for birds that hatched between $2345 \mathrm{~h}$ and $0700 \mathrm{~h}$, approximate hatch time was estimated based on the appearance of the chick (i.e., wetness of down feathers).

\subsection{Dosing solutions}

Neat DE-71 (Great Lakes Chemical Corporation, Kalamazoo, MI, USA) was used in this study. Due to the viscous nature of the material, DE-71 was warmed for $5 \mathrm{~min}$, and approximately $200 \mathrm{mg}$ was transferred to a 5-ml volumetric flask to which $50 \mu$ acetone was added and then diluted with corn oil (Sigma-Aldrich, St. Louis, MO, USA). The DE-71 solution was mixed for $1 \mathrm{~h}$ at $55^{\circ} \mathrm{C}$, and then further diluted in volumetric flasks containing vehicle (corn oil plus acetone at $1 \%$ by total volume) to make nominal concentrations of $0.2,2$ and $20 \mu \mathrm{g} D E-71$ per $0.5 \mu$ l solution ( $0.5 \mu \mathrm{l}$ was the volume administered per gram egg). Analytical recoveries were $90 \%, 116 \%$ and $128 \%$, respectively and thus the actual DE-71 doses were 0.18 , 2.32, and $25.7 \mu \mathrm{g}$ per $0.5 \mu$ l solution.

\subsection{Administration of $D E-71$}

Tern and kestrel eggs were injected after about 101 and $121 \mathrm{~h}$ of incubation, respectively, which corresponds to about d 4 of chicken development. The blunt (cap) end of each egg was cleaned with an alcohol swab, and a $0.32-\mathrm{cm}$ hole was drilled through the cap. Oil solutions were heated to $40^{\circ} \mathrm{C}$, and each egg was air cell injected with vehicle or DE-71 solution at a volume of $0.5 \mu \mathrm{l} \mathrm{g}^{-1}$ egg. Randomly selected tern eggs were injected with vehicle (controls, $n=19), 0.2 \mu \mathrm{g}(n=12), 2 \mu \mathrm{g}(n=12)$, or $20 \mu \mathrm{g}(n=17)$ of DE- 
$71 \mathrm{~g}^{-1}$ egg. Randomly selected kestrel eggs were injected with vehicle $(n=36)$ or $20 \mu \mathrm{g} \mathrm{DE}-71 \mathrm{~g}^{-1}(n=34)$. The hole in the shell was sealed with a vinyl acetate adhesive and the eggs were held vertical at room temperature for $30 \mathrm{~min}$ to allow the corn oil to spread over the inner shell membrane and then returned to the incubator.

\subsection{Embryo survival, hatching and tissue collection}

Survival through $90 \%$ of the incubation period, incidence of pipping, and hatching success were determined. Embryos that died or failed to pip were evaluated for stage of development and abnormalities, edema and teratogenicity. Each hatchling was weighed, crown-rump length determined, and then sacrificed by decapitation. The yolk sac, liver (minus the gall bladder), spleen, bursa of Fabricius, and thyroids were removed and weighed. A portion of the liver, and the bursa, spleen and thyroids were fixed in phosphate-buffered formalin for histopathology. The remainder of the liver was split between cryovials, rapidly frozen in liquid nitrogen and stored at $-80^{\circ} \mathrm{C}$ for biochemical assays.

Vehicle-injected controls that were infertile or died early in incubation were prepared for chemical analysis to determine background contamination. Moisture loss was determined (Heinz et al., 2009a), and egg contents were removed, transferred to a chemically-clean jar, and frozen at $-80^{\circ} \mathrm{C}$ for chemical analyses.

\subsection{Skeletal preparations and histopathology}

The carcass of each hatchling was stored in $70 \%$ ethanol, and subsequently cleared and stained by the method of Karnofsky (1965). Crown-rump, tibiotarsus, metatarsus, femur, humerus and ulna lengths were measured to the nearest $\mathrm{mm}$, and visually inspected for deformities. Formalin-fixed liver, kidney, spleen, bursa of Fabricius and thyroids were embedded in paraffin, sectioned, mounted on slides, and stained with hematoxylin and eosin (American HistoLabs, Gaithersburg, MD, USA). A subset of 27 common tern samples (control, $n=5 ; 0.2 \mu \mathrm{g} \mathrm{g}^{-1} \mathrm{egg}, n=5 ; 2 \mu \mathrm{g} \mathrm{g}^{-1} \mathrm{egg}$, $n=5$; $20 \mu \mathrm{g} \mathrm{g}^{-1} \mathrm{egg}, n=12$ ) was examined for unusual findings, abnormalities, and severity grading of findings (not remarkable, minimal, mild, moderate, and moderately severe) by a Board Certified Veterinary Pathologist (Experimental Pathology Laboratories, Inc., Sterling, VA, USA).

\subsection{Hepatic oxidative stress and oxidative DNA in hatchlings}

Liver tissue was analyzed for four measures of oxidative stress: total sulfhydryls (TSH), total glutathione (TotGSH), reduced glutathione (GSH), and thiobarbituric acid reactive substances (TBARS). Protein-bound sulfhydryls (PBSH; TSH minus GSH), oxidized glutathione (GSSG; [TotGSH-GSH]/2), and the ratio of GSSG to GSH (GSSG:GSH) were calculated using the measured endpoints. Liver tissue from tern and kestrel hatchlings was also analyzed for 8-hydroxy-deoxy-guanosine (8-OH-dG), a genotoxic measure of oxidative stress. The details of these assays are described in the Supplementary material (SM-1).

\subsection{Chemical analysis of dosing solutions and eggs}

Concentrations of DE-71 in dosing solutions, and organochlorine pesticides, total PCBs, and PBDEs in infertile eggs or those that died early in incubation were quantified as previously described (Chen et al., 2008; McKernan et al., 2010), with some modifications (Supplementary material, SM-2).

\subsection{Statistical analysis}

Data were analyzed using SAS ${ }^{\circledR}$ (SAS Institute, Cary, NC, USA). For terns, survival to $90 \%$ of incubation, pipping and hatching success, and incidence of histopathological anomalies were analyzed using contingency analysis with the Bonferroni Correction to account for multiple treatment group comparisons. For continuously distributed variables, residuals were tested for normality (ShapiroWilk test statistic, normal probability plots) and homogeneity of variances. Log transformations were used when data violated one of the assumptions. For terns, duration to hatch, organ weights, bone lengths and biochemical endpoints in hatchlings were analyzed using one-way analysis of variance followed by Tukey's HSD method of multiple comparison $(\alpha \leqslant 0.05$ for statistical significance, and $0.051<\alpha \leqslant 0.080$ for marginal significance). Since there were only two groups in the kestrel study, endpoints were compared using Student's $t$-test. A single suspect outlier in the kestrel study was identified and subsequently excluded using both Grubb's test and Cooks D statistic.

\section{Results}

\subsection{Background contamination of eggs}

Low levels of contaminants were detected in control tern and kestrel eggs that were infertile or died early in incubation. Tern eggs ( $n=5$; 1 egg excluded due to poor recovery of analytes) contained $<0.08 \mu \mathrm{g} \mathrm{g}^{-1} \mathrm{ww}$ of $p, p^{\prime}$-DDE, DDMU (1-chloro-2,2-bis( $p$ chlorophenyl)ethylene), cis-nonachlor, trans-nonachlor, MC5 (octachloro isomer in technical chlordane; Karlsson et al., 2009), mirex, and hexachlorobenzene, $<0.45 \mu \mathrm{g} \mathrm{g}^{-1}$ of total PCBs, $<0.052 \mu \mathrm{g} \mathrm{g}^{-1}$ of total PBDEs. Kestrels eggs $(n=3)$ contained $<0.002 \mu \mathrm{g} \mathrm{g}^{-1}$ of $p, p^{\prime}$-DDE and hexachlorobenzene, $<0.07 \mu \mathrm{g} \mathrm{g}^{-1}$ of total PCBs, and levels of total PBDEs $\left(<0.004 \mu \mathrm{g} \mathrm{g}^{-1}\right)$ were less than $10 \%$ of that detected in terns. Seventeen other organochlorine pesticides and analytes were not detected in tern or kestrel eggs (Supplementary material, SM-3).

\subsection{Survival to $90 \%$ incubation, pipping and hatching success}

For vehicle-injected tern eggs (control group), survival to $90 \%$ of incubation, and pipping and hatching success, were $87.5 \%, 81.2 \%$ and $81.2 \%$, respectively (Table 1$)$. Moisture loss $(n=40$ hatched eggs) averaged $14.5 \%$ by the pipping stage. There were no differences in survival, pipping and hatching success among the DE-71 doses and controls $(p>0.14)$. Likewise, for kestrel eggs there were no differences in survival to $90 \%$ of incubation, and pipping and hatching success between controls and DE-71-treated eggs $(p>0.15)$. Moisture loss ( $n=50$ hatched eggs) averaged $13 \%$ at pipping.

Mortality occurred early in incubation in terns, but near the end of incubation in kestrels. For tern eggs, most of the losses occurred between days 5 and 12 of incubation in the 2 and $20 \mu \mathrm{g} D-71 \mathrm{~g}^{-1}$ egg doses (4 eggs lost at each dose), but there were few losses in other groups thereafter (Table 1 ). In terns, there was no difference in survival from pipping to hatching for controls (13 pipped, 13 hatched) and for all DE-71 treated eggs (27 pipped, 28 hatched) $(p=1.00)$. In contrast, there was a pronounced decrease in survival from pip to hatch in DE-71-treated kestrels. Of the 29 DE-71-treated kestrel eggs that pipped, 7 failed to hatch, while of the 30 control eggs that pipped, only 2 failed to hatch $(p=0.08)$. Comparison of losses from pip to hatch stage was marginally different between the two species $(p=0.052)$.

There was no dose-response relation between quantity of DE-71 administered and mean time to hatch in terns (Fig. 1a). 
Table 1

Survival of embryos to $90 \%$ incubation, pipping and to hatching.

\begin{tabular}{|c|c|c|c|c|c|c|c|c|c|}
\hline \multirow[t]{3}{*}{ Species } & \multirow[t]{3}{*}{ Endpoint } & \multicolumn{2}{|l|}{ Controls } & \multicolumn{6}{|c|}{ Dose $\left(\mu \mathrm{g}\right.$ DE-71 $\mathrm{g}^{-1}$ egg $)$} \\
\hline & & \multirow[t]{2}{*}{ Successful $/ n$} & \multirow[t]{2}{*}{$\%$} & \multicolumn{2}{|l|}{0.2} & \multicolumn{2}{|l|}{2} & \multicolumn{2}{|l|}{20} \\
\hline & & & & Successful $/ n$ & $\%$ & Successful $/ n$ & $\%$ & Successful $/ n$ & $\%$ \\
\hline \multirow[t]{3}{*}{ Common tern } & Survival to $90 \%$ & $14 / 16$ & 87.5 & $10 / 11$ & 90.9 & $7 / 11$ & 63.6 & $12 / 16$ & 75 \\
\hline & Pipped & $13 / 16$ & 81.2 & $9 / 11$ & 81.8 & $7 / 11$ & 63.6 & $12 / 16$ & 75 \\
\hline & Hatched & $13 / 16$ & 81.2 & $8 / 11$ & 72.7 & $7 / 11$ & 63.6 & $12 / 16$ & 75 \\
\hline \multirow[t]{3}{*}{ American kestrel } & Survival to $90 \%$ & $31 / 32$ & 96.9 & & & & & $29 / 30$ & 96.7 \\
\hline & Pipped & $30 / 32$ & 93.8 & & & & & $29 / 30$ & 96.7 \\
\hline & Hatched & $28 / 32$ & 87.5 & & & & & $22 / 30$ & 73.3 \\
\hline
\end{tabular}
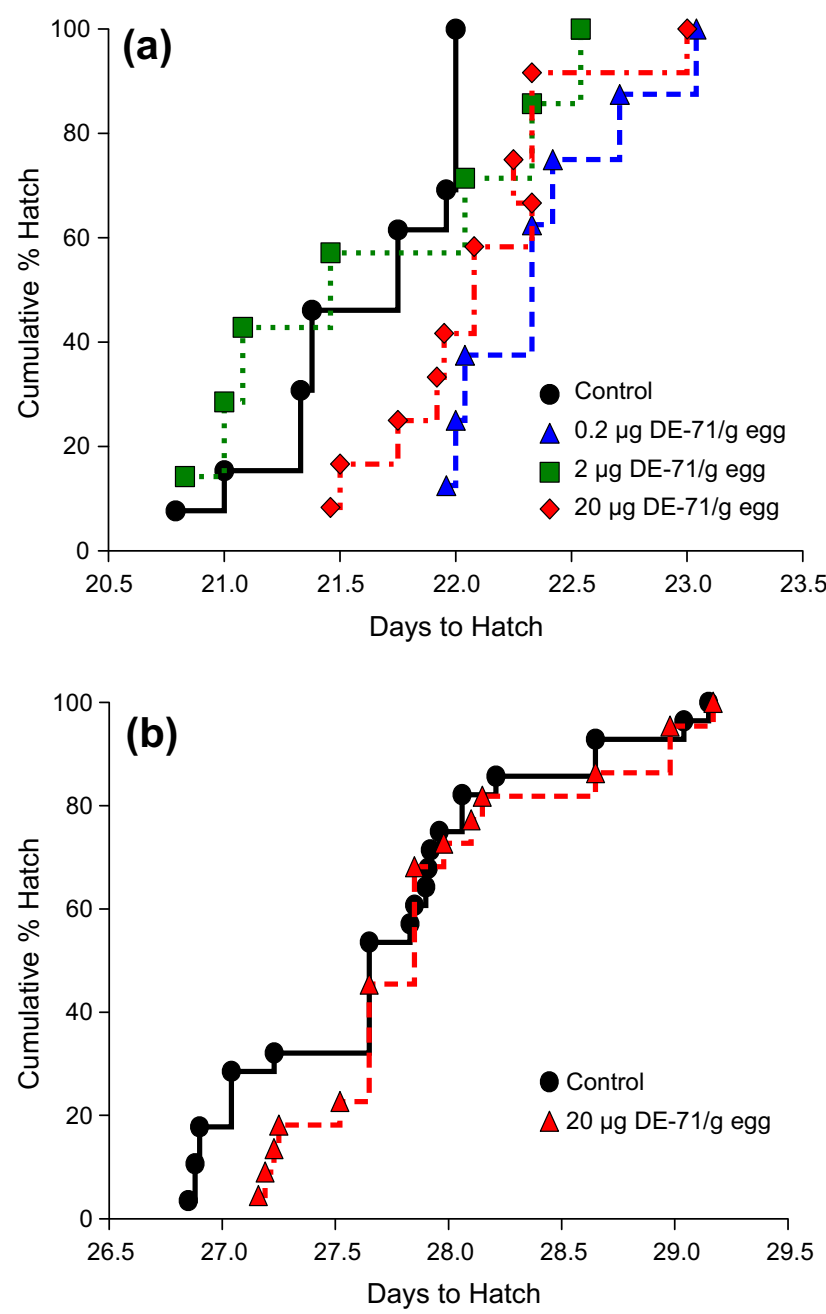

Fig. 1. Cumulative percent hatch for (a) common terns and (b) American kestrels.

However, when all DE-71 treatment groups were combined into a single group, the DE-71-treated tern eggs hatched $0.44 \mathrm{~d}$ later than controls ( $21.59 \pm 0.12$ vs. $22.03 \pm 0.10 \mathrm{~d}, p=0.014)$ (Fig. $2 \mathrm{a}$ ). A different pattern was observed in American kestrels (Fig. 1b). The first 8 eggs to hatch were all controls (Fisher's Exact Test, $p=0.006$ ). However, by the end of the study, there was no difference in mean time to hatch between controls and DE-71-treated kestrel eggs ( $27.71 \pm 0.12$ vs. $27.89 \pm 0.12 \mathrm{~d}, p=0.29)$ (Fig. $2 \mathrm{~b}$ ).

\subsection{Organ weights and bone lengths}

No gross deformities were observed in tern or kestrel hatchlings. However, three DE-71- treated kestrels that failed to hatch
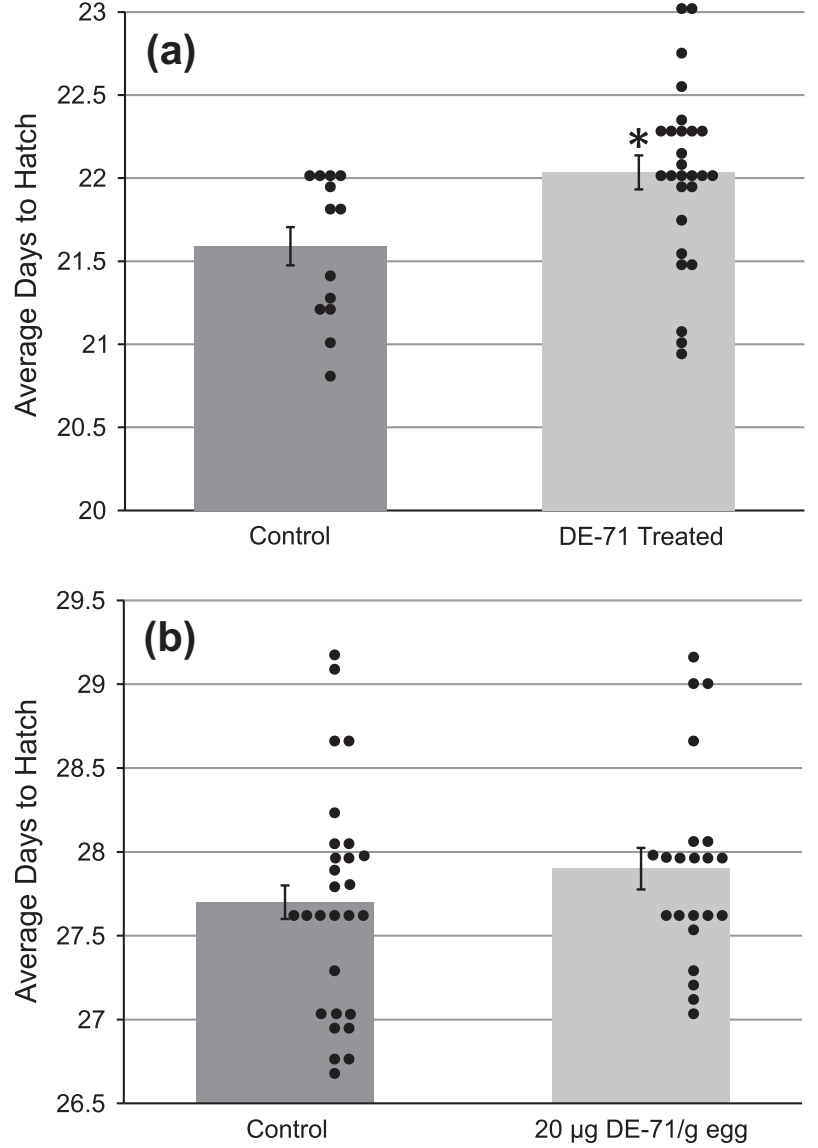

Fig. 2. Average days ( \pm standard error) to hatch for (a) common terns and (b) American kestrels, ${ }^{*}=p<0.05$.

exhibited edema in the head and neck region. For terns, crownrump lengths and the weight of the entire embryo, yolk sac, liver, bursa, thyroids, and the organ-to-body weight ratios for liver, bursa and thyroids did not differ among groups. However, both spleen weight and spleen-to-body weight ratio were only greater in the $2 \mu \mathrm{g} \mathrm{g}^{-1}$ DE-71 dose compared to controls ( $p=0.05$ and 0.03 , respectively). In kestrel hatchlings, crown-rump length, body, yolk sac, liver, spleen, and bursa weights and organ-to-body weight ratios did not differ between groups. Total thyroid weight was less in DE-71-treated kestrels compared to controls $(p=0.036)$. However, the thyroid to body weight ratio was only marginally lower in treated birds $(p<0.075)$. Liver-to-body weight ratio and weight of the left thyroid were marginally smaller in DE-71-treated hatchlings compared to controls $(p<0.075)$.

In hatchling terns, the length of the tibiotarsus, metatarsus, femur, humerus and ulna did not differ among groups $(p>0.17)$. Likewise, for kestrel hatchlings, tibiotarsus, metatarsus, femur 
Table 2

Hepatic oxidative stress and DNA damage endpoints for terns and kestrels ${ }^{a}$.

\begin{tabular}{|c|c|c|c|c|c|}
\hline \multirow[t]{2}{*}{ Species } & \multirow[t]{2}{*}{ Endpoints } & \multirow{2}{*}{$\begin{array}{l}\text { Controls } \\
(n=13)\end{array}$} & \multicolumn{3}{|c|}{ Dose $\left(\mu \mathrm{g} \mathrm{DE}-71 \mathrm{~g}^{-1} \mathrm{egg}\right)$} \\
\hline & & & $\begin{array}{l}0.2 \\
(n=8)\end{array}$ & $\begin{array}{l}2 \\
(n=7)\end{array}$ & $\begin{array}{l}20 \\
(n=12)\end{array}$ \\
\hline \multirow[t]{8}{*}{ Common tern } & Total sulfhydryls $\left(\mu \mathrm{mol} \mathrm{g}{ }^{-1}\right)$ & $42.6 \pm 2.54$ & $41.7 \pm 3.11$ & $46.1 \pm 3.23$ & $43.9 \pm 1.58$ \\
\hline & Protein-bound sulfhydryls ( $\mu \mathrm{mol} \mathrm{g}{ }^{-1}$ ) & $34.6 \pm 2.25$ & $33.9 \pm 2.76$ & $38.0 \pm 4.10$ & $35.9 \pm 1.41$ \\
\hline & Total glutathione $\left(\mu \mathrm{mol} \mathrm{g}{ }^{-1}\right)$ & $10.0 \pm 0.47$ & $9.74 \pm 0.57$ & $10.2 \pm 0.58$ & $9.97 \pm 0.28$ \\
\hline & Reduced glutathione $\left(\mu \mathrm{mol} \mathrm{g}{ }^{-1}\right)$ & $8.06 \pm 0.35$ & $7.78 \pm 0.37$ & $8.16 \pm 0.41$ & $7.95 \pm 0.20$ \\
\hline & Oxidized glutathione $\left(\mu \mathrm{mol} \mathrm{g}^{-1}\right)$ & $0.99 \pm 0.12$ & $0.98 \pm 0.14$ & $1.04 \pm 0.13$ & $1.01 \pm 0.07$ \\
\hline & Oxidized glutathione:reduced glutathione & $0.12 \pm 0.01$ & $0.13 \pm 0.02$ & $0.13 \pm 0.01$ & $0.13 \pm 0.01$ \\
\hline & Thiobarbituric acid reactive substances $\left(\mathrm{nmol} \mathrm{g}^{-1}\right)$ & $4.94 \pm 0.73$ & $4.33 \pm 0.59$ & $4.10 \pm 0.37$ & $4.30 \pm 0.29$ \\
\hline & 8-Hydroxy-deoxyguanosine $\left(\mathrm{pg} \mathrm{g}^{-1}\right)$ & $556 \pm 123^{B}$ & $582 \pm 60.1^{\mathrm{A}, \mathrm{B}}$ & $705 \pm 188^{\mathrm{A}}$ & $668 \pm 89.6^{\mathrm{A}, \mathrm{b}}$ \\
\hline \multirow[t]{9}{*}{ American kestrel } & & $(n=28)$ & & & $(n=22)$ \\
\hline & Total sulfhydryls ( $\mu \mathrm{mol} \mathrm{g}^{-1}$ ) & $25.8 \pm 1.05$ & & & $30.0 \pm 1.82$ \\
\hline & Protein-bound sulfhydryls ( $\left.\mu \mathrm{mol} \mathrm{g}^{-1}\right)$ & $20.6 \pm 0.94$ & & & $24.3 \pm 1.60$ \\
\hline & Total glutathione $\left(\mu \mathrm{mol} \mathrm{g}^{-1}\right)$ & $6.99 \pm 0.23$ & & & $7.92 \pm 0.39$ \\
\hline & Reduced glutathione $\left(\mu \mathrm{mol} \mathrm{g}^{-1}\right)$ & $5.15 \pm 0.13$ & & & $5.65 \pm 0.24^{\dagger}$ \\
\hline & Oxidized glutathione $\left(\mu \mathrm{mol} \mathrm{g}{ }^{-1}\right)$ & $0.92 \pm 0.06$ & & & $1.13 \pm 0.08^{*}$ \\
\hline & Oxidized glutathione:reduced glutathione & $0.18 \pm 0.01$ & & & $0.20 \pm 0.01$ \\
\hline & Thiobarbituric acid reactive substances $\left(\mathrm{nmol} \mathrm{g}^{-1}\right)$ & $2.48 \pm 0.13$ & & & $2.89 \pm 0.20^{\dagger}$ \\
\hline & 8-Hydroxy-deoxyguanosine $\left(\mathrm{pg} \mathrm{g}^{-1}\right)$ & $427 \pm 88.8$ & & & $570 \pm 143^{*}$ \\
\hline
\end{tabular}

a Values are mean \pm standard deviation. Means with different captial letter superscripts differ, $0.05<p<0.078$.

b $n=11$, due to lost sample.

$p<0.05$.

$p<0.07$.

and ulna length did not differ between groups ( $p>0.49$ ), but humerus length was shorter in DE-71-treated kestrels $(p=0.002)$.

\subsection{Histopathology}

In a detailed evaluation of a subset of the tern samples, liver and thyroids were unremarkable and generally uniform among control and DE-71-treated hatchlings, with the exception of minimal thyroid follicular hyperplasia in one hatchling in the $2 \mu \mathrm{g} \mathrm{g}^{-1}$ group. A seemingly increased prevalence of splenic hematopoiesis was apparent in DE-71 hatchlings (6 of 12 samples at $20 \mu \mathrm{g} \mathrm{g}^{-1} \mathrm{egg}$ ) compared to controls ( 1 of 5 samples), but this was not significant $(p>0.252)$. Other changes were modest and not unusual for hatchling birds (occasional presence of heterophilic granulocytes in kidney, lymphocyte proliferation in spleen and bursa).

\subsection{Oxidative stress and DNA damage measures}

There were no differences in hepatic oxidative stress endpoints for tern hatchlings $(p>0.65)$ (Table 2$)$. However, for kestrel hatchlings, means of all oxidative stress endpoints were numerically greater in the DE-71 group compared to controls. Differences were significant $(p=0.045)$ for the concentration of GSSG, and marginally significant for GSH $(p=0.064)$ and TBARS $(p=0.065)$.

In terns, the analysis of variance for $8-\mathrm{OH}-\mathrm{dG}$ was significant $(p=0.034)$, but pair-wise differences were marginally apparent, with the top doses exceeding controls $\left(2 \mu \mathrm{g} \mathrm{DE}-71 \mathrm{~g}^{-1} \mathrm{egg}\right.$, $p=0.068 ; 20 \mu \mathrm{g} \mathrm{DE}-71 \mathrm{~g}^{-1}$ egg, $p=0.077$ ) (Table 2 ). The concentration of $8-\mathrm{OH}-\mathrm{dG}$ was greater in kestrels receiving $20 \mu \mathrm{g}$ DE-71 $\mathrm{g}^{-1}$ compared to controls $(p<0.001)$.

\section{Discussion}

\subsection{Background contamination and use of common tern and American kestrel eggs}

Concentrations of polyhalogenated contaminants in common tern eggs from Poplar Island and American kestrel eggs from our captive colony, were well-below known reproductive effect thresholds in birds (Beyer and Meador, 2011). Notably, values of $p, p^{\prime}$-DDE and total PCBs in tern eggs collected in the present study (i.e., $<0.08$ and $<0.45 \mu \mathrm{g} \mathrm{g}^{-1} \mathrm{ww}$, respectively) were lower than levels found in Chesapeake Bay tern eggs collected in 1994 (South Sand Point off Barren Island) and 1997 (Bodkin Island) (i.e., $\leqslant 0.21$ and $\leqslant 2.47 \mu \mathrm{g} \mathrm{g}^{-1} \mathrm{ww}$, respectively; J.B. French, USGS PWRC, unpublished data; French et al., 2001). This apparent difference presumably reflects greater exposure during the 1990s.

Total PBDE concentrations in Forster's tern eggs collected from San Francisco Bay between 2000 and 2003 ranged up to $63 \mu \mathrm{g} \mathrm{g}^{-1} \mathrm{lw}$ (She et al., 2008). By adjusting for lipid and moisture loss during incubation, and converting lw back to the ww of a fresh egg, it is estimated that annual average PBDE values in Forster's tern eggs ranged from 0.39 to $1.56 \mu \mathrm{g} \mathrm{g}^{-1} \mathrm{ww}$. In contrast, background concentrations of total PBDEs in eggs from the closely related common tern used in the present study were nearly two orders of magnitude lower. In combination, these data suggest that the tern eggs from Poplar Island were suitable for evaluating the embryotoxicity of DE-71, and concentration of other compounds quantified were unlikely to be a confounding factor. As previously reported, kestrel eggs from our captive colony contain low concentrations of these same analytes, and based on their reported sensitivity to DE-71 (McKernan et al., 2009), could serve as a positive control.

\subsection{Survival and morphological responses following DE-71 administration}

Common tern and American kestrel eggs injected with ultralow volumes of corn oil vehicle exhibited good survival through incubation, and pipping and hatching rates were comparable to other artificial incubation studies conducted at our laboratory (Hoffman et al., 1998; McKernan et al., 2009; Heinz et al., 2009b). In previous studies, administration of up to $20 \mu \mathrm{g}$ DE-71 $\mathrm{g}^{-1}$ egg did not affect survival through hatching in chickens, mallards, and black-crowned night-herons (Nycticorax nycticorax), but pipping and hatching success were reduced in kestrels at doses of 10 and $20 \mu \mathrm{g} \mathrm{g}^{-1}$ egg (McKernan et al., 2009, 2010). In contrast, administration of $20 \mu \mathrm{g} \mathrm{g}^{-1}$ egg did not affect kestrel pipping or hatching success in the present study. Nonetheless, DE-71 did 
delay hatching of kestrels, possibly reflecting retarded development or a weakened condition of some embryos that could place this altricial species at a survival disadvantage. Although differing from the dose-dependent decrease in pipping and hatching reported by McKernan et al. (2009), these more subtle effects do not invalidate earlier findings. Notably, dietary exposure to DE71 has also been reported to delay the onset of egg laying in kestrels, and reduce egg size and mass (Fernie et al., 2009). At nominal doses up to $20 \mu \mathrm{g} \mathrm{g}^{-1} \mathrm{egg}$, survival and hatching success of common terns was not affected, suggesting that they are relatively tolerant of DE-71. Based on DE-71 solubility in the injection vehicle, it is not possible to administer greater doses to discriminate potential differences in sensitivity among seemingly tolerant avian species (i.e., chicken, mallard, black-crowned night-heron, common tern) in our test system. In the present study, we did not rigorously determine the uptake of DE-71 into the contents of common tern eggs. However, our previous uptake studies demonstrated that only $18.8-29.6 \%$ of the administered dose is absorbed through the air cell membrane over the course of incubation (McKernan et al., 2010). Thus, at the greatest dose (analytically determined to be $25.7 \mu \mathrm{g} \mathrm{DE}-71 \mathrm{~g}^{-1} \mathrm{egg}$ ), about $4.8-7.6 \mu \mathrm{g} \mathrm{DE}-71 \mathrm{~g}^{-1}$ egg on a ww basis may have actually entered egg contents. This exceeds the average values of PBDEs found in Caspian tern (Sterna caspia), Forster's tern, least tern, and California clapper rail (Rallus longirostris obsoletus) eggs from San Francisco Bay by a factor of 4.4 to 6.9 (She et al., 2008).

Mortality of developing tern embryos principally occurred during the first half of incubation rather than at pipping and hatching, which differs from the time-course DE-71-induced mortality in kestrel eggs in the present and related studies (McKernan et al., 2009). It is possible that this difference in the timing of mortality could reflect more rapid transfer of DE-71 across the air cell membrane or greater sensitivity of early stage tern embryos compared to kestrels; for some toxicants, early developmental stages (primary organogenesis) in bird eggs are the most sensitive period for embryotoxicity (Hill and Hoffman, 1984; DeWitt et al., 2005).

The delayed hatching of DE-71-treated tern eggs may have implications for post-hatching survival of precocial wild birds. A delay in hatch could result in weakened or exhausted tern chicks that might lead to a fitness and survival disadvantage (e.g., less able to seek vegetative cover, more vulnerable to predation or other environmental factors). Unlike altricial kestrels, terns nest in open areas and their nests consist of a small scrape. Semiprecocial tern chicks must be able to consume small food items within 1-3 h of hatching and seek shelter in nearby vegetation by 2-3 d post-hatch in order to avoid predation and overheating.

As previously noted (McKernan et al., 2009), DE-71 does not seem to evoke teratogenic effects in bird embryos, although some edema was observed in kestrels that failed to hatch. In general, organ weights and bone lengths were not affected by DE-71, although there was evidence of splenic enlargement and enhanced hematopoiesis in some of the treated terns. However, these subtle effects were neither dose-dependent nor statistically significant, and probably transient and of limited biological consequence. Kestrels treated with DE-71 had shorter humerus length and total thyroid weight was reduced, which may have contributed to the initial delay of hatch in kestrels, and could affect post-hatching survival. As previously discussed (Fernie et al., 2005b; McKernan et al., 2009), PBDE exposure decreases thyroxine (T4) concentration in rodents and nestling kestrels, possibly by altering plasma transport of $\mathrm{T} 4$ through competitive binding mechanisms and hepatic T4 glucouronidation. However, thyroid histology, often considered the "gold standard" of thyrotoxic effects, was unremarkable in both kestrels and terns in the present study, a finding similar to that in other avian studies (Fernie et al., 2005b; McKernan et al., 2009).

\subsection{Oxidative stress and DNA damage}

Oxidative stress is one mechanism by which brominated flame retardants evoke toxicity. In contrast to DE-71-treated terns, kestrel hatchlings exhibited significant increases in GSSG, GSH, and TBARS concentrations. Increased GSSG has been previously observed in kestrels (Fernie et al., 2005b) and earthworms (Eisenia fetida; Xie et al., 2011) exposed to PBDEs, yet in the present study a marginal increase in GSH concentration was apparent, thus leaving the GSSG:GSH ratio unchanged. The increase in GSH levels is potentially a result of de novo synthesis of GSH as a defense mechanism against reactive oxyradicals associated with DE-71 exposure. Our findings also suggest that compensatory mechanisms are activated, which would stabilize the GSSG:GSH ratio, as described in other studies (Xie et al., 2011).

Common terns exhibited greater baseline levels of GSH than kestrels. Interestingly, a study in mice (Mus musculus) found that that DE-71 toxicity is mediated by oxidative stress and that toxicity is modulated by increased cellular GSH levels (Giordano et al., 2008). Knockout mice (those with a reduced ability to synthesize GSH) exposed to DE-71 had significantly lower concentrations of GSH than their wild-type counterparts, and were more susceptible to oxidative attack resulting in cytotoxicity and apoptosis (Giordano et al., 2008). These findings may imply that the greater GSH concentrations in terns may afford protection at the tested doses, preventing any increase in oxidative stress above baseline values.

Hepatic thiols also protect against the effects of oxidative stress, but are depleted under severe stress due to oxidation and binding with oxyradicals (Hoffman et al., 2005). For common terns no changes were observed in concentrations of TSH and PBSH. Although not significant, both TSH and PBSH concentrations were consistently greater in the DE-71-treated kestrels than controls. In a previous study, Fernie et al. (2005b) reported a significant positive association of TSH and PBSH with BDE-183 and PBSH with BDE-99 in post-fledging American kestrels. Thus, the seemingly greater thiol concentrations are consistent with the TBARS and glutathione data indicating that the exposure conditions induced mild oxidative stress in kestrels.

Oxyradicals that produce damage can also bind to DNA. In the present study, concentrations of $8-\mathrm{OH}-\mathrm{dG}$, a marker of oxidative injury and damage to DNA bases, were clearly elevated in kestrels and to a lesser degree in terns. This manifestation of oxidative stress, if exacerbated beyond the capacity of DNA repair mechanisms and excretion rates, could lead to strand breaks and changes in gene expression (Fraga et al., 1990). These findings are consistent with studies that have demonstrated that brominated flame retardants, and in particular BDE-47, can cause oxidative stress and DNA damage (Fernie et al., 2005b; Albina et al., 2010; Pellacani et al., 2012). Fraga et al. (1990) also note that at the time of embryogenesis, when cell proliferation rates are high, much of the genome may become exposed to increased oxidative damage. Thus, developing embryos exposed to a maternally deposited contaminant that has an oxidative mechanism of action may have a higher risk of disease progression, changes in gene expression, or even epigenetic effects may be manifest in subsequent generations.

\section{Conclusions}

Although the toxic effects of DE-71 on developing kestrels were not as remarkable as in our previous work (McKernan et al., 2009), a qualitative evaluation of a combination of endpoints (weight of evidence approach) suggests that common tern embryos, and perhaps other tern species are less sensitive to PBDEs than are kestrels. Limited sample size is often a challenging issue in 
comparative toxicity studies with wild bird eggs. Nonetheless, this pattern of embryotoxicity, with kestrels being more sensitive than common terns, has been observed in egg injection studies involving methylmercury (Heinz et al., 2009b) and PCB congener 126 (Hoffman et al., 1998). An evaluation of the sensitivity of 25 terrestrial vertebrate species to various classes of contaminants (persistent organic pollutants, mercury, lead shot, petroleum crude oil, and organophosphorus insecticides) using a combination of laboratory and field data indicates that common terns are moderately sensitive compared to other avian species (Golden and Rattner, 2003). While it is certainly possible that PBDEs and other contaminants in San Francisco Bay may be adversely affecting tern reproduction, California gull (Larus californicus) depredation may be a more significant factor that is limiting nest success, particularly for the endangered California least tern (Riensche, 2007).

\section{Acknowledgements}

The authors thank R. Michael Erwin, P.C. McGowan, S.E. Warner, W.C. Bauer and M.M. Maxey for assistance in collecting tern and kestrel eggs, E. Harvey and M.J. La Guardia for analysis of eggs and dosing solutions, K.M. Eisenreich for bone length measurements, J.C. Wolf for histopathological evaluations, M. Sedlak and $K$. Taberski for valuable discussions at various stages of the study, and M.A. McKernan and H.M. Ohlendorf for reviewing a draft of this manuscript. This work was funded in part by the Regional Monitoring Program for Water Quality in San Francisco Bay (SFEI Contract 869). Use of product names does not imply endorsement by the US Government.

\section{Appendix A. Supplementary material}

Supplementary data associated with this article can be found, in the online version, at http://dx.doi.org/10.1016/j.chemosphere. 2013.05.030.

\section{References}

Albina, M.L., Alonso, V., Linares, V., Belles, M., Sirvent, J.J., Domingo, J.L., Sanchez, D.J. 2010. Effects of exposure to BDE-99 on oxidative status of liver and kidney in adult rats. Toxicology 271, 51-56.

Beyer, W.N., Meador, J.P., 2011. Environmental Contaminants in Biota: Interpreting Tissue Concentrations. CRC Press, Taylor and Francis Group, Boca Raton.

Chen, D., Hale, R.C., 2010. A global review of polybrominated diphenyl ether flame retardant contamination in birds. Environ. Int. 36, 800-811.

Chen, D., La Guardia, M.J., Harvey, E., Amaral, M., Wohlfort, K., Hale, R.C., 2008 Polybrominated diphenyl ethers in peregrine falcon (Falco peregrinus) eggs from the northeastern US. Environ. Sci. Technol. 42, 7594-7600.

Chipley, R.M., Fenwick, G.H., Parr, M.J., Pashley, D.N., 2003. The American Bird Conservancy Guide to the 500 Most Important Bird Areas in the United States. Random House, New York.

DeWitt, J.C., Meyer, E.B., Henshel, D.S., 2005. Environmental toxicity studies using chickens as surrogates for wildlife: effects of injection day. Arch. Environ. Con. Tox. 48, 270-277.

Fernie, K.J., Mayne, G., Shutt, J.L., Pekarik, C., Grasman, K.A., Letcher, R.J., Drouillard, K. 2005a. Evidence of immunomodulation in nestling American kestrels (Falco sparverius) exposed to environmentally relevant PBDEs. Environ. Pollut. 138, 485-493.

Fernie, K.J., Shutt, J.L., Mayne, G., Hoffman, D., Letcher, R.J., Drouillard, K.G., Ritchie, I.J., 2005b. Exposure to polybrominated diphenyl ethers (PBDEs): changes in thyroid, vitamin A, glutathione homeostasis, and oxidative stress in American kestrels (Falco sparverius). Toxicol. Sci. 88, 375-383.

Fernie, K.J., Shutt, J.L., Ritchie, I.J., Letcher, R.J., Drouillard, K., Bird, D.M., 2006. Changes in the growth, but not the survival, of American kestrels (Falco sparverius) exposed to environmentally relevant polybrominated diphenyl ethers. J. Toxicol. Env. Heal Part A 69, 1541-1554.

Fernie, K.J., Shutt, J.L., Letcher, R.J., Ritchie, J.I., Sullivan, K., Bird, D.M., 2008. Changes in reproductive courtship behaviors of adult American kestrels (Falco sparverius) exposed to environmentally relevant levels of the polybrominated diphenyl ether mixture, DE-71. Toxicol. Sci. 102, 171-178.

Fernie, K.J., Shutt, J.L., Letcher, R.J., Ritchie, I.J., Bird, D.M., 2009. Environmentally relevant concentrations of DE-71 and HBCD alter eggshell thickness and reproductive success of American kestrels. Environ. Sci. Technol. 43, 21242130.

Fraga, C.G., Shigenaga, M.K., Park, J.W., Degan, P., Ames, B.N., 1990. Oxidative damage to DNA during aging: 8-hydroxy-2'-deoxyguanosine in rat organ DNA and urine. Proc. Natl. Acad. Sci. USA 87, 4533-4537.

French Jr., J.B., Nisbet, I.C., Schwabl, H., 2001. Maternal steroids and contaminants in common tern eggs: a mechanism of endocrine disruption? Comp. Biochem. Phys. C 128, 91-98.

Giordano, G., Kavanagh, T.J., Costa, L.G., 2008. Neurotoxicity of a polybrominated diphenyl ether mixture (DE-71) in mouse neurons and astrocytes is modulated by intracellular glutathione levels. Toxicol. Appl. Pharm. 232, 161-168.

Golden, N.H., Rattner, B.A., 2003. Ranking terrestrial vertebrate species for utility in biomonitoring and vulnerability to environmental contaminants. Rev. Environ. Contam. Toxicol. 176, 67-136.

Heinz, G.H., Stebbins, K.R., Klimstra, J.D., Hoffman, D.J., 2009a. A simplified method for correcting contaminant concentrations in eggs for moisture loss. Environ. Toxicol. Chem. 28, 1425-1428.

Heinz, G.H., Hoffman, D.J., Klimstra, J.D., Stebbins, K.R., Kondrad, S.L., Erwin, C.A., 2009b. Species differences in the sensitivity of avian embryos to methylmercury. Arch. Environ. Con. Tox. 56, 129-138.

Henny, C.J., Kaiser, J.L., Grove, R.A., Johnson, B.L., Letcher, R.J., 2009. Polybrominated diphenyl ether flame retardants in eggs may reduce reproductive success of ospreys in Oregon and Washington, USA. Ecotoxicology 18, 802-813.

Henny, C.J., Grove, R.A., Kaiser, J.L., Johnson, B.L., Furl, C.V., Letcher, R.J., 2011. Wastewater dilution index partially explains observed polybrominated diphenyl ether flame retardant concentrations in osprey eggs from Columbia River Basin, 2008-2009. Ecotoxicology 20, 682-697.

Hill, E.F., Hoffman, D.J., 1984. Avian models for toxicity testing. J. Am. Coll. Toxicol. 3, 357-376.

Hoffman, D.J., Melancon, M.J., Klein, P.N., Eisemann, J.D., Spann, J.W., 1998. Comparative developmental toxicity of planar polychlorinated biphenyl congeners in chickens, American kestrels, and common terns. Environ. Toxicol. Chem. 17, 747-757.

Hoffman, D.J., Spalding, M.G., Frederick, P.C., 2005. Subchronic effects of methylmercury on plasma and organ biochemistries in great egret nestlings. Environ. Toxicol. Chem. 24, 3078-3084.

Johansson, A.K., Sellström, U., Lindberg, P., Bignert, A., De Wit, C.A., 2009. Polybrominated diphenyl ether congener patterns, hexabromocyclododecane, and brominated biphenyl 153 in eggs of peregrine falcons (Falco peregrinus) breeding in Sweden. Environ. Toxicol. Chem. 28, 9-17.

Karlsson, H., Oehme, M., Scherer, G., 2009. Isolation of the chlordane compounds U82, MC5, MC7, and MC8 from technical chlordane by HPLC including structure elucidation of U82 and determinationof ECD and NICI-MS repsonse factors. Environ. Toxicol. Chem. 33, 1353-1358.

Karnofsky, D.A., 1965. The chick embryo in drug screening: survey of teratological effects observed in the 4-day-old chick embryo. In: Wilson, J.G., Warkany, J.K. (Eds.), Teratology: Principles and Techniques. University of Chicago Press, Chicago, IL, USA, pp. 194-213.

Klimstra, J.D., Stebbins, K.R., Heinz, G.H., Hoffman, D.J., Kondrad, S.R., 2009. Factors related to the artificial incubation of wild bird egos. Avian Biol. Res. 2, 121-131.

McKernan, M.A., Rattner, B.A., Hale, R.C., Ottinger, M.A., 2009. Toxicity of polybrominated diphenyl ethers (DE-71) in chicken (Gallus gallus), mallard (Anas platyrhynchos), and American kestrel (Falco sparverius) embryos and hatchlings. Environ. Toxicol. Chem. 28, 1007-1017.

McKernan, M.A., Rattner, B.A., Hatfield, J.S., Hale, R.C., Ottinger, M.A., 2010. Absorption and biotransformation of polybrominated diphenyl ethers DE-71 and DE-79 in chicken (Gallus gallus), mallard (Anas platyrhynchos), American kestrel (Falco sparverius) and black-crowned night-heron (Nycticorax nycticorax) eggs. Chemosphere 79, 100-109.

Pellacani, C., Buschini, A., Galati, S., Mussi, F., Franzoni, S., Costa, L.G., 2012. Evaluation of DNA damage induced by 2 polybrominated diphenyl ether flame retardants (BDE-47 and BDE-209) in SK-N-MC cells. Int. J. Toxicol. 31, 372-379.

Rahn, H., Ar, A., 1974. The avian egg: incubation time and water loss. Condor 76, $147-152$.

Riensche, D.L., 2007. California least tern habitat enhancement and nesting in the East Bay Regional Park District, California. TW Sect. Wil. Soc. 43, 62-71.

She, J., Holden, A., Adelsbach, T.L., Tanner, M., Schwarzbach, S.E., Yee, J.L., Hooper, K., 2008. Concentrations and time trends of polybrominated diphenyl ethers (PBDEs) and polychlorinated biphenyls (PCBs) in aquatic bird eggs from San Francisco Bay, CA 2000-2003. Chemosphere 73, S201-S209.

US Environmental Protection Agency, 2012. Polybrominated diphenyl ether (PBDEs) action plan summary. <www.epa.gov/oppt/existingchemicals/pubs/ actionplans/pbde.html>

Xie, X., Wu, Y., Zhu, M., Zhange, Y.-K., Wang, X., 2011. Hydroxyl radical generation and oxidative stress in earthworms (Eisenia fetida) exposed to decabromodiphenyl ether (BDE-209). Ecotoxicology 20, 993-999. 


\title{
Supplementary Material
}

\section{Comparative embryotoxicity of a pentabrominated diphenyl ether mixture to common terns (Sterna hirundo) and American kestrels (Falco sparverius)}

\author{
Barnett A. Rattner", Rebecca S. Lazarus ${ }^{\text {a }}$, Gary H. Heinz ${ }^{\text {a }}$, Natalie K. Karouna-Renier a, \\ Sandra L. Schultz ${ }^{\mathrm{a}}$, and Robert C. Hale ${ }^{\mathrm{b}}$
}

\begin{abstract}
a Patuxent Wildlife Research Center, U.S. Geological Survey, clo BARC-East, Building 308, 10300 Baltimore Avenue, Beltsville, MD 20705, USA

${ }^{\mathrm{b}}$ Department of Environment and Aquatic Animal Health, Virginia Institute of Marine Science, Gloucester Point, VA 23062, USA
\end{abstract}

* Corresponding author. Tel.: +1 3014975671

Fax: 3014975624.

E-mail address: brattner@usgs.gov

SM-1. Hepatic oxidative stress and oxidative DNA damage in hatchlings (details of assay methods)

Liver samples were thawed on ice and homogenized in phosphate-buffered saline $(0.274$ $\mathrm{M} \mathrm{NaCl}, 0.0054 \mathrm{M} \mathrm{KCl}, 0.0238 \mathrm{M}$ sodium phosphate, $\mathrm{pH}$ 7.4; Fisher BioReagents, Waltham, MA, USA) at $200 \mu \mathrm{g} \mu \mathrm{l}^{-1}$. The homogenate was centrifuged at $10,000 \mathrm{~g}$ for $10 \mathrm{~min}$ at $4^{\circ} \mathrm{C}$ and aliquots of the supernatant were frozen at $-80^{\circ} \mathrm{C}$. For GSH, GSSG, and TotGSH analysis, liver supernatant was thawed and diluted to $12.5 \mu \mathrm{g} \mu \mathrm{l}^{-1}$ in assay buffer $(0.137 \mathrm{M} \mathrm{NaCl}, 0.0027 \mathrm{M}$ $\mathrm{KCl}, 0.0119 \mathrm{M}$ sodium phosphate, $\mathrm{pH}$ 7.4) and analyzed using the DetectX® Glutathione 
Fluorescent Detection Kit (Arbor Assays, Ann Arbor, MI, USA) following the manufacturer's protocol. Concentrations of TBARS (indicative of lipid peroxidation) were determined using the QuantiChrom $^{\text {TM }}$ TBARS Assay Kit (Bioassay Systems, Hayward, CA, USA); sample supernatant was thawed and diluted to $100 \mu \mathrm{g} \mathrm{l}^{-1}$ in assay buffer. To $300 \mu \mathrm{l}$ of diluted sample, $50 \mu 1$ of $48 \%$ TCA were added and then the manufacturer's protocol was followed. Total sulfhydryls were determined in supernatant diluted to 5 or $6.3 \mu \mathrm{g} \mu \mathrm{l}^{-1}$ assay buffer using the Measure-iT TM Thiol Assay Kit (Invitrogen-Molecular Probes, Inc., Eugene, OR, USA). All assays were analyzed using a Fluostar Omega microplate reader (BMG Labtech Inc., Cary, NC, USA). The limit of quantitation [LOQ; mean +10 (standard deviations of blanks across three assays)] were $0.06 \mu \mathrm{M}, 11.3 \mu \mathrm{M}, 0.20 \mu \mathrm{M}$, and $0.26 \mu \mathrm{M}$ for TBARS, TSH, GSH, and TotGSH, respectively. Each sample was analyzed in duplicate with a coefficient of variation $(\mathrm{CV}$; mean \pm standard deviation) of $2.6 \pm 2.6 \%, 4.4 \pm 3.7 \%, 2.9 \pm 2.5 \%$, and $2.1 \pm 1.5 \%$ for TBARS, TSH, GSH, and TotGSH, respectively. Samples for which the intra-assay variability exceeded $20 \%$ were reanalyzed (Krotzky and Zeeh, 1995). Each of the three plates used in the analysis of the samples included three pools of reference material (i.e., liver from kestrel, common tern, and tree swallow, Tachycineta bicolor) to account for inter-assay variability. The inter-assay CVs for the three reference pools were $16.5,22.3$ and $2.5 \%$ for TBARS; 4.4, 5.2 and $22.8 \%$ for TSH; 13.5 , 11.4 and $20.1 \%$ for GSH; and 4.9, 5.4 and $12.5 \%$ for TotGSH.

Liver tissue from tern and kestrel hatchlings was analyzed for 8-OH-dG. DNA was purified from thawed liver samples using the Puregene Tissue Extraction Kit (Qiagen, Gaithersburg, MD, USA) following the manufacturer's protocol. A NanoDrop ${ }^{\mathrm{TM}}$ 8-Sample Spectrophometer (Thermo Scientific, Wilmington, DE, USA) was used to determine DNA concentration of DNA and purity. Before DNA digestion, samples were normalized to a 
concentration of $15 \mu \mathrm{g} \mathrm{ml}^{-1}$ DNA hydration buffer. Briefly, samples were denatured by heating for $10 \mathrm{~min}$ at $100^{\circ} \mathrm{C}$, cooled on ice for $5 \mathrm{~min}$, and then $50 \mu \mathrm{l}$ of $40 \mathrm{mM}$ sodium acetate, $0.4 \mathrm{mM}$ $\mathrm{ZnCl}_{2}$ was added to each tube. Next, $50 \mu 1$ of $5 \mathrm{U} \mathrm{ml}^{-1}$ of nuclease P1 (Sigma-Aldrich) was added and samples incubated at $37^{\circ} \mathrm{C}$ for $30 \mathrm{~min}$. The $\mathrm{pH}$ was adjusted with $20 \mu \mathrm{l}$ of $1 \mathrm{M}$ Tris$\mathrm{HCl}(\mathrm{pH} 7.5)$, followed by the addition of $15 \mu 1$ of $10 \mathrm{U} \mathrm{ml}^{-1}$ alkaline phosphatase. Samples were incubated again for $30 \mathrm{~min}$, denatured at $95^{\circ} \mathrm{C}$ for $10 \mathrm{~min}$, and placed on ice. Final concentrations were fluorometrically determined using the Cayman Chemical 8-OH-dG EIA Kit (Cayman Chemical Company, Ann Arbor, MI, USA). Standard curves were fitted and concentrations were determined by using a 4-parameter fit $\left(R^{2}>0.998\right)$, to the entire range of concentrations. The LOQ was $10.3 \mathrm{pg} \mathrm{m}^{-1}$. Intra-assay variability of duplicates was $6.3 \pm 4.2 \%$. Plates included blanks and two Japanese quail (Coturnix japonica) reference samples to monitor inter-assay variability (4.1 and $11.5 \%$, respectively; $n=5$ assays).

Krotzky, A.J., Zeeh, B., 1995. Immunoassays for residue analysis of agrochemicals: proposed guidelines for precision, standardization and quality control. Pure Appl. Chem. 67, 2065- 2088.

\section{SM-2. Chemical analysis of dosing solutions and eggs (details of analytical methods)}

Dosing solutions containing DE-71 were diluted in hexane and an internal standard ( $p$ terphenyl) was added. Tern and kestrel egg analyses were conducted based on the methods of Chen et al. (2008). Eggs were freeze-dried, and a surrogate standard (200 ng of 2, 3, 4, 4', 5, 6hexabromodiphenyl ether, BDE-166; Cambridge Isotope Laboratories, Inc., Andover, MA, USA) was added to each sample. Spiked egg samples were subjected to accelerated solvent extraction (Dionex ASE 200, Sunnyvale, CA, USA), and extracts were purified by size exclusion 
chromatography (SEC, Envirosep-ABC ${ }^{\circledR}, 350$ x 21.1 mm. column; Phenomenex, Torrance, CA, USA). Each post-SEC extract was reduced in volume, added to the top of a solid phase 2-g silica glass extraction column (Isolute, International Sorbent Technology, Ltd., Hengoed Mid Glamorgan, UK) and eluted with $3.5 \mathrm{ml}$ hexane (fraction one), followed by $6.5 \mathrm{ml}$ of $60: 40$ hexane/dichloromethane (DCM) and then $8 \mathrm{ml} \mathrm{DCM}$ (fraction two). The second fraction, containing the compounds of interest, was reduced in volume and solvent exchanged to hexane. Decachlorodiphenyl ether (DCDE; $100 \mathrm{ng}$ ) was then added as the internal standard (Ultra Scientific, North Kingstown, RI, USA) and the extracts analyzed for 57 PBDE congeners (single or co-eluting pairs). Identification and quantitation were done by gas chromatography mass spectrometry using selective ion monitoring (GC-MS/SIM).

Diluted dosing solutions and purified egg extracts were analyzed by GC (6890N, Agilent Technologies, Palo Alto, CA, USA) with MS detection (JMS-GC Mate II, JEOL, Peabody, MA, USA). Sample aliquots $(1 \mu \mathrm{l})$ were introduced into the $\mathrm{GC}$ split/splitless injector, equipped with a glass liner $(1 \mathrm{~mm}$, i.d.), and separated on a $15-\mathrm{m}$ DB-5HT column $(0.25 \mathrm{~mm}$ i.d., $0.1 \mu \mathrm{m}, \mathrm{J} \&$ W Scientific, Folsom, CA, USA). The injector temperature was $300^{\circ} \mathrm{C}$ and initial carrier gas (He) head pressure was 50 psi. Four min after sample injection, the split vent was opened and pressure reduced to $15.2 \mathrm{psi}$ (flow $1.2 \mathrm{ml} \mathrm{min}^{-1}$ ). Column flow rate was kept constant $(1.2 \mathrm{ml}$ $\min ^{-1}$, temperature compensated) throughout the remaining portion of the analysis. Initial column oven temperature was $90^{\circ} \mathrm{C}$, held for $4 \mathrm{~min}$, then increased to $150^{\circ} \mathrm{C}$ at $30^{\circ} \mathrm{C} \mathrm{min}{ }^{-1}$, then $10^{\circ} \mathrm{C} \min ^{-1}$ to $300^{\circ} \mathrm{C}$, and held for $20 \mathrm{~min}$. Column oven temperature was then increased to $350^{\circ} \mathrm{C}$ at $30^{\circ} \mathrm{C} \mathrm{min}^{-1}$ and held at $350^{\circ} \mathrm{C}$ for $5 \mathrm{~min}$. Total run time was $47.7 \mathrm{~min}$.

The MS was operated in the electron capture negative ionization (ECNI) mode (methane reagent gas $(99.99 \%)$ using SIM. Ion source temperature was $200^{\circ} \mathrm{C}$ and transfer line was 
maintained at $300^{\circ} \mathrm{C}$. Quantitation ions for PBDEs were $m / z 79\left(\left[{ }^{79} \mathrm{Br}\right]^{-}\right), 81\left(\left[{ }^{81} \mathrm{Br}\right]^{-}\right)$.

Confirmation ions were 486 and $488 \mathrm{~m} / \mathrm{z}$ for decabromodiphenyl ether (BDE-209). A five-point calibration curve $\left(\mathrm{R}^{2}>0.995\right)$ was constructed from the analysis of calibration standards (Wellington Laboratories, Inc., Ontario, Canada). The quantitation limits for the 57 PBDE congeners in eggs were $0.2 \mathrm{ng} \mathrm{g}^{-1} \mathrm{ww}$ and $5 \mathrm{ng} \mathrm{ml}^{-1}$ for analytes in the corn oil solutions.

Purified egg extracts were analyzed using a multipoint calibration curve generated using the responses of the authentic standards of the targeted analytes (viz., 41 organochlorine pesticides and metabolites, octachlorodibenzodioxin, octachlorodibenzofuran, and 68 individual or co-eluting PCB congeners) versus that of the internal standard. A Varian Saturn 4D ion trap GC-MS operating in the electron ionization mode was used to analyze the samples. A DB-5 60 $\mathrm{m} \times 0.33 \mathrm{~mm}$ id $\times 25 \mu \mathrm{m}$ film capillary column ( $\&$ \& Scientific) was installed in the GC. The GC was programmed as follows: $75^{\circ} \mathrm{C} 1 \mathrm{~min}$ hold, $75^{\circ} \mathrm{C}$ to $350^{\circ} \mathrm{C}$ at $4^{\circ} \mathrm{C} \mathrm{min}^{-1}, 350^{\circ} \mathrm{C}$ hold 15.25 min. The MS ion mass range collected was $100-650 \mathrm{~m} / \mathrm{z}$. Individual analytes were quantified using selected ions. The quantitation limit for analytes in eggs was $0.2 \mathrm{ng} \mathrm{g}^{-1} \mathrm{ww}_{\text {. }}$

\section{SM-3. Background contamination of eggs (analytes not detected)}

Compounds were not detected in eggs included $o, p^{\prime}$-DDD, $o, p^{\prime}$-DDE, $o, p^{\prime}$-DDT, $p, p^{\prime}$ DDD, $p, p^{\prime}$ DDT, total BHC isomers (alpha, beta, gamma and lindane), several components of technical chlordane (heptachlor, trans-chlordane, heptachlor epoxide isomer B, oxychlordane, cis-chlordane, and components that are not fully characterized including compound C, compound $\mathrm{K}, \mathrm{MC1}, \mathrm{MC} 2, \mathrm{MC} 3, \mathrm{MC} 6, \mathrm{MC} 7$, and $\mathrm{MC} 8$,), aldrin, dieldrin, methoxychlor, methoxychlor olefin, pentachloroanisole, methoxy triclosan, endosulfan (endosulfan I, II, 
endosulfan sulfate), endrin and metabolites (endrin-ketone, endrin-aldehyde), octachlordibenzodioxin, and octachlorodibenzofuran. 